\title{
A Case of Thyrotoxic Periodic Paralysis in a 16-Year- Old Adolescent
}

\author{
Moon Bae Ahn, M.D., \\ You Jin Jung, M.D., \\ Moon Hee Lee, M.D., \\ Won Kyoung Cho, M.D. \\ and Byung-Kyu Suh, M.D.
}

Department of Pediatrics, The Catholic University of Korea School of Medicine, Seoul, Korea

Received: 18 April, 2012

Revised: 20 June, 2012

Accepted: 20 June, 2012

Address for correspondence:

Byung-Kyu Suh, M.D.

Department of Pediatrics,

The Catholic University of Korea School of Medicine, 222 Banpodaero, Seocho-gu, Seoul 137-701, Korea

Tel: +82.2-2258-6185

Fax: $+82.2-532-6185$

E-mail: suhbk@catholic.ac.kr
Thyrotoxic periodic paralysis (TPP) is a transient illness characterized by muscle weakness often associated with hypokalemia during thyrotoxic state. Hypokalemia is induced by thyroid hormone excess through stimulation of Na-K ATPase which pumps extracellular potassium ions into the cell. Muscle weakness resolves when serum potassium level is corrected, but the condition may recur when there is thyrotoxicosis. TPP is most commonly reported in Asian males aged between 20 to 40 years and it is rare in children and adolescents. We report a 16-year-old patient previously diagnosed with Graves' disease who showed recurrent episodes of TPP.

Key Words: Hypokalemic periodic paralysis; Hyperthyroidism; Graves disease; Adolescent

\section{Introduction}

갑상샘중독 주기성 마비(thyrotoxic periodic paralysis, TPP)는 갑상샘 항진증에서 드 물게 동반되는 합병증으로 저칼륨혈증에 의한 골격근의 이완성 마비를 특징으로 하는 질 환이다. 갑상샘 호르몬의 과잉은 $\mathrm{Na}-\mathrm{K}$ ATPase를 자극하여 칼륨을 세포 내로 이동시켜 저칼륨혈증을 초래한다는 것이 병인으로 알려져 있다 ${ }^{1)}$. 갑작스런 근육의 약화나 마비를 보여 내원하게 되며 혈액검사에서 저칼륨혈증과 갑상샘 항진증을 보인다. 상지보다는 하 지를 주로 침범하며, 원위부보다 근위부를 잘 침범한다. 근육의 마비는 일시적이며 저칼 륨혈증이 교정되면 회복되나, 갑상샘 기능항진 상태에서 반복적으로 발생할 수 있다. 일 반적으로 갑상샘 질환은 여성에서 더 많이 발생하는데 반해 TPP는 남성에서 더 많이 발 생하며, 서양인에 비해 동양인에서 더 흔하달. 호발 연령은 주로 20 대에서 40 대 사이로 소아와 청소년 연령에서는 흔하지 않다. 국내에서도 성인에서 발생한 TPP 증례는 다수 보고되었으나, 소아청소년 연령에서 발생한 TPP 증례는 최근 $\mathrm{Oh}$ 등히이 기술한 1례 만이 보고되었다. 저자들은 12 세 때 그레이브스병을 진단받고 항갑상선제를 복용 중이었던 16 세 남아에서 TPP가 반복하여 발생한 경우를 경험하였기에 문헌 고찰과 함께 보고하는 바이다.

\section{Case Report}

환 아: 윤 $\bigcirc$, 남자, 16 세

주 소: 내원일 아침부터 시작된 양측 하지의 근력저하

과거력: 12세에 본원에서 그레이브스병을 진단 받고 항갑상샘 약제(methimazole) 를 복용하며 갑상샘 기능이 정상 범위에서 유지되던 중 내원 3 주전 시행한 검사에서 thyroid-stimulating hormone (TSH) $0.12 \mathrm{mIU} / \mathrm{L}$ (정상치, 0.17-4.05 mIU/L), free thyroxine (fT4) $2.88 \mathrm{ng} / \mathrm{dL}$ (정상치, $0.85-1.86 \mathrm{ng} / \mathrm{dL}$ ), triiodothyronine (T3) 3.3 
$\mathrm{ng} / \mathrm{mL}$ (정상치, $0.78-1.82 \mathrm{ng} / \mathrm{mL}$ )로 갑상샘 항진증 소 견 보여 내원 2주전부터 methimazole을 $5 \mathrm{mg}$ /day에서 10 $\mathrm{mg} /$ day로 증량하고 levothyroxine $50 \mathrm{mcg} /$ day 보충은 중 단한 상태였음.

가족력: 특이사항 없음

현병력: 4년 전부터 그레이브스병을 진단 받고 약물치료 하던 환아로 최근 특별한 증세 없이 지내던 중 내원 당일 아 침 일어나서부터 양측 하지의 근력이 저하되어 걷지 못하여 본원 응급실을 방문하였다. 내원 전일 소주를 마신 것이 평 소와 다른 점이었다.

진찰 소견: 내원 시 신장 $177 \mathrm{~cm}$ (75-90 백분위수), 체중 $71.5 \mathrm{~kg}$ (75-90 백분위수), 체질량지수 $22.8 \mathrm{~kg} / \mathrm{m}^{2}$ (75 백 분위수) 이었다. 활력 징후는 혈압 $110 / 70 \mathrm{mmHg}$, 맥박수 106 회/분, 호흡수 22 회/분, 체온 $36.5^{\circ} \mathrm{C}$ 이었다. 의식은 명 료하였다. 안구돌출이 있었고, Grade $1 / 3$ 의 갑상샘비대가 촉진되었으며 결절은 만져지지 않았다. 흥부 청진상 호흡음 은 정상이었고 심음은 규칙적이었다. 복부 진찰에서 특이소 견은 없었다. 신경학적 진찰에서 양측 하지의 근력이 근위부 는 Grade $3 / 5$, 원위부는 Grade $4 / 5$ 로 저하되었고, 무릎 심 부건 반사가 감소되어 있었다. 양측 하지의 감각 신경 기능 은 정상이었다.

검사실 소견: 혈액검사에서 백혈구 $8,550 / \mathrm{mm}^{3}$ (중성구 $60.7 \%$, 림프구 $27.4 \%$ ), 혈색소 $13.2 \mathrm{~g} / \mathrm{dL}$, 혈소판 $279,000 /$ $\mu \mathrm{L}$, 적혈구침강속도(erythrocyte sedimentation rate, $\mathrm{ESR}) 2 \mathrm{~mm} / \mathrm{hr}$ 이었다. 생화학 검사에서 당 $128 \mathrm{mg} / \mathrm{dL}$, blood urea nitrogen (BUN) $11.5 \mathrm{mg} / \mathrm{dL}$, creatinine 0.46 $\mathrm{mg} / \mathrm{dL}$, aspartate aminotransferase (AST) $16 \mathrm{IU} / \mathrm{L}$, alanine aminotransferase (ALT) 22 IU/L, lactate dehydrogenase (LDH) 316 IU/L, creatine phosphokinase 117 $\mathrm{IU} / \mathrm{L}, \mathrm{C}$-reactive protein $\langle 0.02 \mathrm{mg} / \mathrm{dL}$ 로 정상이었다. 전해질 검사에서 $\mathrm{Na} 142 \mathrm{mEq} / \mathrm{L}, \mathrm{K} 2.5 \mathrm{mEq} / \mathrm{L}, \mathrm{Cl} 107$ $\mathrm{mEq} / \mathrm{L}, \mathrm{Ca} 8.7 \mathrm{mg} / \mathrm{dL}, \mathrm{P} 2.3 \mathrm{mg} / \mathrm{dL}, \mathrm{Mg} 1.9 \mathrm{mg} / \mathrm{dL}$ 로 저칼륨혈증이 확인되었다. 소변 검사와 동맥혈 가스 검사 에서 이상 소견은 없었다. 갑상샘 기능검사에서 TSH 0.09 mIU/L (0.17-4.05), fT4 $1.87 \mathrm{ng} / \mathrm{dL}(0.85-1.86)$, T3 1.8 $\mathrm{ng} / \mathrm{mL}(0.78-1.82)$ 로 갑상샘 기능항진 상태였다. 심전도 검사에서 동성빈맥, T파 역전, QT 간격 연장을 보였다. 흥부
$\mathrm{X}$-선 검사에서는 특이소견 없었다.

치료 및 경과: 환아의 기저질환과 임상증상, 검사결과를 토대로 그레이브스병에 합병된 TPP 진단 하에 정맥으로 칼 륨 보충을 시행하였다. 2 병일째 칼륨이 $4.5 \mathrm{mEq} / \mathrm{L}$ 로 교정 되었고 증상이 소실되었다. 3 병일째 양측 하지의 근력 및 심 부건 반사는 정상 소견 보였으며, 칼륨 $4.7 \mathrm{mEq} / \mathrm{L}$ 로 유지되 어 퇴원하였다.

두 번째 발병: 퇴원 후 외래 추적하며 항갑상샘 약제 치료 유지하던 중 3 주 만에 전과 같은 양상으로 아침에 일어나서 부터 양측 하지 근력이 저하되어 외래를 방문하였다. 혈액 검사에서 칼륨 $2.9 \mathrm{mEq} / \mathrm{L}$ 로 저칼륨혈증의 소견을 보였으 며, TSH $0.1 \mathrm{mIU} / \mathrm{L}, \mathrm{fT} 41.21 \mathrm{ng} / \mathrm{dL}$, T3 $1.9 \mathrm{ng} / \mathrm{mL}$ 로 갑 상샘 기능항진 상태였다. TPP 재발 진단 하에 정맥으로 칼 륨 보충을 시행하였고, 2 병일째 칼륨 $4.3 \mathrm{mEq} / \mathrm{L}$ 로 교정되 고 증상 소실되어 3 병일째 퇴원하였다.

세 번째 발병: 퇴원 10 개월 후 환아는 아침에 일어나서부 터 이전보다 더 심한 정도의 양측 하지 근력저하가 있어 타 병원 응급실을 방문하였고, 칼륨 $3.3 \mathrm{mEq} / \mathrm{L}$ 로 감소되어 칼 륨이 포함된 수액치료 후 본원 응급실로 전원 되었다. 본원 내원 시 칼륨 $4.2 \mathrm{mEq} / \mathrm{L}$ 로 교정되었으며 증상은 호전된 상 태였다. 두 번째 퇴원 후 외래 추적하면서 갑상샘 기능이 정 상으로 유지되었으나, 내원 10 일전 외래에서 시행한 검사에 서 TSH $0.28 \mathrm{mIU} / \mathrm{L}, \mathrm{fT} 42.35 \mathrm{ng} / \mathrm{dL}, \mathrm{T} 32.69 \mathrm{ng} / \mathrm{mL}$ 로 다시 갑상샘 항진증 소견 보여 내원 1주 전부터 methimazole 을 하루 $20 \mathrm{mg}$ 으로 증량하여 복용 중이었다. 입원 시에도 TSH $0.06 \mathrm{mIU} / \mathrm{L}, \mathrm{fT} 41.65 \mathrm{ng} / \mathrm{dL}, \mathrm{T} 32.65 \mathrm{ng} / \mathrm{mL}$ 로 갑 상샘 항진증이 지속되고 있었다. 추가적인 칼륨 보충 없이 혈청 칼륨치는 정상으로 유지되었고 증상 소실되어 3 병일 째 퇴원하였다. 퇴원 2주 뒤에 갑상샘 기능은 정상화되었으 며, 항갑상샘 약제를 감량하여 복용 중으로 현재까지 1 년간 $\mathrm{TPP}$ 의 재발은 없는 상태이다(Table 1).

\section{Discussion}

주기성 마비는 여러 가지 원인에 의해 발생되는데, 그 중 갑상샘중독 주기성 마비는 갑상샘 항진증의 드문 합병증으 로 골격근의 가역적인 마비를 초래한다. 마비의 기전으로

Table 1. Thyroid function and serum potassium level at each episode of thyrotoxic periodic paralysis

\begin{tabular}{lcccccc}
\hline & Age & T3 & fT4 & TSH & Serum potassium & Serum potassium \\
& $(\mathrm{yr})$ & $(0.78-1.82 \mathrm{ng} / \mathrm{mL})$ & $(0.85-1.86 \mathrm{ng} / \mathrm{dL})$ & $(0.17-4.05 \mathrm{mlU} / \mathrm{L})$ & $\begin{array}{c}\text { at presentation }(\mathrm{mEq} / \mathrm{L}) \\
\text { at discharge }(\mathrm{mEq} / \mathrm{L})\end{array}$ \\
\hline Diagnosis of Graves' disease & 12.9 & 5.43 & 4.30 & 0.03 & 4.2 & - \\
1st TPP & 16.3 & 1.80 & 1.87 & 0.09 & 2.5 & 4.6 \\
2nd TPP & 16.4 & 1.90 & 1.21 & 0.10 & 2.9 & 5.1 \\
3rd TPP & 17.3 & 2.65 & 1.65 & 0.06 & 3.3 & 4.0 \\
\hline
\end{tabular}

Abbreviations: fT4, free thyroxine; T3, triiodothyronine; TPP, thyrotoxic periodic paralysis; TSH, thyroid-stimulating hormone. 
는 저칼륨혈증이 밀접한 관계가 있는 것으로 알려져 있다 1). Rosenfeld)는 1902년에 주기성 마비와 갑상샘 항진증의 연관성에 대해 처음으로 기술하였다. 1931년에 Dunlap 과 Kepler ${ }^{5}$ 가 가족성 주기성 마비와 유사한 임상증세를 보이는 4 명의 갑상샘 항진증 환자를 보고하면서 이 질환이 가족성 주기성 마비와는 구분되는 질환으로 인식되기 시작되었다. 1993년 Kang 등 ${ }^{6}$ 의 연구에서 한국인에서의 빈도는 갑상 샘 항진증 환자의 $2 \%$ 로, 일본인 $(1.9 \%)^{7)}$ 이나 중국인 $(1.8 \%)^{8)}$ 과 비슷한 것으로 나타났다. 동양인에 비해 서양인에서는 드 문 질환으로 미국에서는 갑상샘 항진증 환자의 0.1-0.2\%에 서 발생하는 것으로 보고되었다 ${ }^{2)}$. 일반적으로 갑상샘 질환 은 여성에서 더 많이 발생하지만 TPP는 남성에서 4-20배 더 많이 발생한다 ${ }^{7,8}$. TPP의 호발 연령은 20 대에서 40 대로 청소년 연령에서는 흔하지 않은 것으로 알려져 있다. 대부분 갑상샘 항진증의 가장 흔한 원인인 그레이브스병에서 발생 하지만, 갑상샘 중독증을 초래할 수 있는 중독성 결절성 갑 상샘종, 아급성 갑상샘염, 외인성 갑상샘 중독증 및 $\mathrm{TSH}$ 분 비 뇌하수체 종양 등에서도 발생할 수 있다. 이미 갑상샘 항 진증으로 진단된 환자에서 발생하는 경우가 $80 \%$ 정도이나, $20 \%$ 에서는 $\mathrm{TPP}$ 와 갑상샘 항진증이 동시에 진단되는 것으 로 보고되었당) 선행 유발 인자로는 운동, 탄수화물 과잉섭 취, 알코올, 스트레스, 추위, 감염 등이 있다. 일본에서 조사 된 바로는 과거에 비해 TPP의 발생 빈도가 감소하였는데 이 는 탄수화물의 섭취가 감소하고 칼륨의 섭취가 증가하는 등 식생활이 변화와 관련된 것으로 보인다 ${ }^{9)}$. 저자들이 조사한 바로는 국내에서 청소년기에 발생한 TPP에 대한 보고는 14 세 여아에서 그레이브스병과 TPP가 동시에 진단된 1례만이 있어 ${ }^{3)}$, 본 증례가 두 번째이다.

$\mathrm{TPP}$ 의 발생 기전에서 중요한 것은 저칼륨혈증으로, 이는 갑상샘 호르몬 과잉에 의해 $\mathrm{Na}-\mathrm{K}$ ATPase가 활성화되어 혈 중 칼륨을 세포 내로 이동시킴으로써 초래된다. 따라서 저칼 륨혈증은 있으나 체내 전체 칼륨은 감소되지 않는 것으로 알 려져 있다. Na-K ATPase의 활성도를 증가시키는 것으로 는 갑상샘 호르몬 외에도 인슐린 ${ }^{10)}$, 베타-아드레날린성 카 테콜라민 ${ }^{1}$, 안드로겐 ${ }^{11)}$ 등이 있다. 탄수화물이 많은 음식은 고인슐린혈증을 유발하여 TPP를 유발할 수 있다. 또한 외 상, 추위, 스트레스 등은 베타-아드레날린성 카테콜라민 자 극을 통해 TPP를 유발할 수 있다. TPP가 남자 환자에서 많 이 발생하는 것은 안드로겐에 의해 $\mathrm{Na}-\mathrm{K}$ ATPase 활성도가 증가되는 점으로 일부 설명할 수 있다. 운동시 근육에서 칼 륨이 방출되었다가 휴식 시에 칼륨이 근육 내부로 이동하는 데, TPP도 운동 후 휴식 시에 잘 유발되는 것으로 알려져 있 다. 한편, 일부 환자에서는 혈청 칼륨 수치가 정상을 보여 이 러한 환자에서는 혈청 칼륨의 세포 내로의 이동 외 칼슘펌프 의 활성도 저하나 저인산혈증과 같이 다른 기전에 의해서 마
비가 일어날 가능성도 제시되었다. 마비 시 저칼륨혈증이 있 었던 경우와 정상 칼륨 수치를 보인 경우를 비교했을 때, 임 상양상에는 차이가 없었으나 저칼륨혈증이 있는 경우에서 갑상샘 호르몬 수치가 유의하게 높게 나타나는 것으로 보고 되었다 ${ }^{6)}$. 본 환자의 경우 세 차례 모두 저칼륨혈증이 확인되 었고 칼륨 보충 후 증상이 소실되었기 때문에 저칼륨혈증이 마비의 기전으로 보인다.

$\mathrm{TPP}$ 의 전형적인 임상양상은 하지의 대칭성 이완 마비이 다. 원위부보다 근위부가 더 심하게 침범되어 대퇴부가 가장 심하게 마비된다. 종종 하지와 상지 모두를 침범하기도 하지 만, 상지만 침범하는 경우는 보기 힘들다. 저작근, 발성근, 외안근 및 호흡근도 매우 드물게 침범할 수 있다고 하며, 호 흡근의 마비나 심장마비로 사망한 경우도 보고되었다 ${ }^{12}$. 심 부건 반사는 저하된 소견을 보이며, 감각 기능은 보존된다. 주로 취침 시와 아침 기상 시에 발생하며 낮 시간에는 잘 발 생하지 않는닿. 근육통, 근경직, 근경련 등의 전구증상이 마비가 일어나기 1 시간에서 3 일 전에 나타났다는 보고가 있 다 ${ }^{13)}$. 마비는 대개 수시간에서 수일 동안 지속되며, 칼륨을 투여함으로써 회복을 촉진시킬 수 있다. 대개 갑상샘 항진 증의 출현과 동시에 또는 곧 이어서 마비가 발생하는 것으로 알려져 있다. TPP의 심전도 소견으로는 갑상샘 기능항진에 의한 동성빈맥과 저칼륨혈증에 의한 $\mathrm{T}$ 파의 편평화 또는 역 전, ST 분절 저하, U파의 출현, QT 간격 연장 등이 있는데, 이는 혈청 칼륨이 $2.8 \mathrm{mEq} / \mathrm{L}$ 이하일 때 뚜렷하게 나타난다. 드물게 방실 전도장애, 심방세동, 심실빈맥, 심실세동과 같 은 부정맥을 초래할 수 있다 ${ }^{14)}$.

$\mathrm{TPP}$ 는 갑상샘 중독증 상태에서 전형적인 마비의 임상 양 상을 토대로 진단하게 된다. 급성 이완성 근육 마비를 초래 하는 여러 가지 질환들과 감별을 요하며, 이러한 것으로는 히스테리성 마비, Guillain-Barre 증후군, 다발성 경화증, 중증 근무력증, 폴리오 등이 있다. 주기성 마비의 여러 가지 원인 중에서는 TPP와 임상 증상이 동일한 가족성 저칼륨혈 증성 주기성 마비(familial hypokalemic periodic paralysis, $\mathrm{FHPP}$ )를 감별해야 한다. 가족성 주기성 마비는 상염색체 우성 방식의 유전질환으로 칼슘채널 유전자인 CACNA1. ${ }^{15}$, 나트륨채널 유전자인 $\mathrm{SCN} 4 \mathrm{~A}^{16}$ 등 이온 채널 유전자의 돌연 변이에 의해 초래된다. FHPP도 저칼륨혈증을 보이고 남성 에서 호발한다. 차이점은 $\mathrm{FHPP}$ 는 가족력이 있으며 주로 10 대 전후의 청소년기에 증상이 시작되나, $\mathrm{TPP}$ 는 가족력 없이 주로 20 대에서 40 대에 발생한다. 임상적으로 두 질환의 가 장 큰 감별점은 갑상샘 항진증이 동반되었는가 하는 점이다.

일부 환자에서는 정상 혈청 칼륨 수치를 보이므로 저칼륨 혈증이 진단에 필수적인 것은 아니다. 저칼륨혈증이 있는 경 우에는 칼륨 소실성 신증, 알도스테론 과잉, 또는 저칼륨혈 증을 초래하는 약물 등을 감별해야 한다. 본 환자에서 두 번 
째 발병 시 혈청 마그네슘이 $1.7 \mathrm{mg} / \mathrm{dL}$ (정상치, $1.9-2.5$ $\mathrm{mg} / \mathrm{dL}$ )로 저하되어 있어 저칼륨혈증, 저마그네슘혈증 및 근육의 마비를 초래하는 기텔만 증후군에 대해 SLC12A3 유 전자검사를 시행하였으나 정상이었다. 기텔만 증후군은 상 염색체 열성으로 유전되는 신장 세뇨관 질환으로 16번 염 색체에 위치한 SLC12A3 유전자의 돌연변이에 의해 원위세 관의 thiazide-sensitive sodium-chloride cotransporter (NCCT)에 이상이 초래된다 ${ }^{17)}$. TPP 발생시 저칼륨혈증과 함 께 약 $80 \%$ 의 환자에서는 저인산혈증 소견을 보이고 경미한 저마그네슘혈증도 잘 동반되는 것으로 보고되었다 ${ }^{13)}$.

$\mathrm{TPP}$ 는 근전도 검사를 시행 할 경우 특정 패턴을 관찰할 수 있는데, 단 시간 운동 후 측정된 근 긴장성 전위 및 복합 근육 활동 전위의 진폭에는 변화가 없으며 장 시간 운동 후 복합 근육 활동 전위의 진폭이 늦게 하강하는 소견이 관찰 된다 ${ }^{18)}$. 그러나 이러한 소견은 환자가 마비 증상을 호소하고 있을 당시에만 나타나는 제한 점이 있다. TPP의 확진을 위 해서 당을 투여하여 마비가 유발되는지 확인하는 방법이 있 으며, 당과 인슐린을 병합 투여하여 저칼륨혈증을 유발시켜 마비가 초래되는지 확인할 수 있다 ${ }^{6}$.

$\mathrm{TPP}$ 의 치료는 저칼륨혈증이 동반된 경우 칼륨을 투여하 여 마비의 회복을 촉진시키고 심장 합병증을 예방하는 것이 목적이다. 체내 총칼륨량은 정상이므로 과도한 칼륨 보충 치 료는 고칼륨혈증을 초래할 수 있어 주의해야 한다. 칼륨의 투여는 마비의 예방에는 도움이 되지 않는다. 궁극적으로는 갑상샘 항진증이 정상화되어야 $\mathrm{TPP}$ 의 발생을 막을 수 있으 며, 갑상샘기능이 정상화 되기 전까지 재발을 예방하기 위해 propranolol을 투여할 수 있다 ${ }^{19)}$. 본 환자는 propranolol을 투여하지 않았으나, 재발 방지를 위해서는 propranolol 투여 가 필요하다. 갑상샘 치료 시작 이후 갑상샘 기능이 정상화 될 때까지의 기간에는 유발요인을 피하는 것이 권장되므로 탄수회물이 많은 음식, 알코올, 심한 운동 등은 피해야 한다. 예후는 양호하여 갑상샘 항진증이 정상으로 회복되면 마비 가 잘 발생하지 않는 것으로 알려져 있다. 그러나 드물게 정 상 갑상샘 상태에서도 TPP 발생을 보고한 예가 있다 ${ }^{20)}$.

\section{References}

1) Kubota K, Ingbar SH. Influences of thyroid status and sympathoadrenal system on extrarenal potassium disposal. Am J Physiol 1990;258:E428-35.

2) Kelley DE, Gharib H, Kennedy FP, Duda RJ Jr, McManis PG. Thyrotoxic periodic paralysis. Report of 10 cases and review of electromyographic findings. Arch Intern Med 1989;149:2597-600

3) Oh KW, Jeong JY, Kim JS. A case of thyrotoxic periodic paralysis in adolescent with Graves' disease. J Korean Soc
Pediatr Endocrinol 2011;16:196-200.

4) Rosenfeld M. Akute aufsteigende Lahmung bei Morbus Basedow. Berl Klin Wochnschr 1902;39:538.

5) Dunlap HF, Kepler EJ. A syndrome resembling familial periodic paralysis occurring in the course of exophthalmic goiter. Endocrinology 1931;15:541-6.

6) Kang SY, Kim SH, Kim DY, Woo JT, Yang IM, Kim SW, et al. A clinical study of thyrotoxic periodic paralysis. J Korean Soc Endocrinol 1993;8:19-26.

7) Okinaka S, Shizume K, Iino S, Watanabe A, Irie M, Noguchi A, et al. The association of periodic paralysis and hyperthyroidism in Japan. J Clin Endocrinol Metab 1957;17:1454-9.

8) McFadzean AJ, Yeung R. Periodic paralysis complicating thyrotoxicosis in Chinese. Br Med J 1967;1:451-5.

9) Shizume K, Shishiba Y, Kuma K, Noguchi S, Tajiri J, Ito K, et al. Comparison of the incidence of association of periodic paralysis and hyperthyroidism in Japan in 1957 and 1991. Endocrinol Jpn 1992;39:315-8.

10) Layzer RB. Periodic paralysis and the sodium-potassium pump. Ann Neurol 1982;11:547-52.

11) Fraser CL, Sarnacki P. Na+-K+ ATPase pump function in rat brain synaptosomes is different in males and females. Am J Physiol 1989;257:E284-9.

12) Norris KC, Levine B, Ganesan K. Thyrotoxic periodic paralysis associated with hypokalemia and hypophosphatemia. Am J Kidney Dis 1996;28:270-3.

13) Manoukian MA, Foote JA, Crapo LM. Clinical and metabolic features of thyrotoxic periodic paralysis in 24 episodes. Arch Intern Med 1999;159:601-6.

14) Ee B, Cheah JS. Electrocardiographic changes in thyrotoxic periodic paralysis. J Electrocardiol 1979;12:263-79.

15) Jurkat-Rott K, Lehmann-Horn F, Elbaz A, Heine R, Gregg RG, Hogan K, et al. A calcium channel mutation causing hypokalemic periodic paralysis. Hum Mol Genet 1994;3: 1415-9.

16) Sternberg D, Maisonobe T, Jurkat-Rott K, Nicole S, Launay E, Chauveau D, et al. Hypokalaemic periodic paralysis type 2 caused by mutations at codon 672 in the muscle sodium channel gene SCN4A. Brain 2001;124:1091-9.

17) Simon DB, Nelson-Williams C, Bia MJ, Ellison D, Karet FE, Molina AM, et al. Gitelman's variant of Bartter's syndrome, inherited hypokalaemic alkalosis, is caused by mutations in the thiazide-sensitive Na-Cl cotransporter. Nat Genet 1996; 12:24-30.

18) Fournier E, Arzel M, Sternberg D, Vicart S, Laforet P, Eymard B, et al. Electromyography guides toward subgroups of mutations in muscle channelopathies. Ann Neurol 2004;56:650-61.

19) Lin SH, Lin YF. Propranolol rapidly reverses paralysis, hypokalemia, and hypophosphatemia in thyrotoxic periodic paralysis. Am J Kidney Dis 2001;37:620-3.

20) Rone JK, Brietzke SA. Euthyroid thyrotoxic periodic paralysis. Mil Med 1991;156:434-6. 


\section{6세 청소년에서 발생한 갑상샘중독 주기성 마비 1례}

안문배·정유진·이문희·조원경·서병규

가톨릭대학교 의과대학 소아과학교실

갑상샘 중독성 주기성 마비는 갑상샘 항진증의 드문 합병증으로 소아청소년 연령에서는 발생 보고가 매우 드물다. 저 자들은 그레이브스병으로 치료 중인 16세 남자 청소년에서 저칼륨혈증을 동반한 갑상샘 중독성 주기성 마비가 3 회에 걸쳐 재발한 증례를 경험하였기에 문헌 고찰과 함께 보고하는 바이다. 